\title{
Spillover Effects Across Transnational Industrial Relations Agreements: The Potential and Limits of Collective Action in Global Supply Chains
}

Sarah Ashwin, Chikako Oka, Elke Schüßler, Rachel Alexander and Nora Lohmeyer

Sarah Ashwin, Department of Management, London School of Economics, Houghton Street, London WC2A 2AE, UK; Tel: 0207106 1203; Email: $\underline{\text { S.Ashwin@1se.ac.uk }}$

Chikako Oka School of Management, Royal Holloway, University of London, Egham, Surrey, TW20 0EX; Tel: +44 1784 443363; Email: chika.oka@royalholloway.ac.uk

Elke Schüßler, Institut für Organisation, Johannes Kepler Universität, Altenberger Str. 69, 4040 Linz, Austria; Tel.: +43-732-2468-4440; Email: elke.schuessler@jku.at

Rachel Alexander, Department of Management, London School of Economics, Houghton Street, London WC2A 2AE, UK; Tel: 0207106 1203; Email: R.Alexander@1se.ac.uk

Nora Lohmeyer, Management Department, Freie Universität, Berlin, Boltzmannstraße 20, Room 224A, D-14195 Berlin; Tel: +49 30838 60975; Email: nora.lohmeyer@fu-berlin.de

Acknowledgements:

We are very grateful to Sarosh Kuruvilla for organizing the Global Supply Chains seminar at MIT in November 2017 where we received insightful feedback from the participants, particularly our discussant Matthew Amengual. We are also indebted to Patrick Feuerstein for detailed feedback on an earlier version of this paper, as well as other participants at the research colloquium at SOFI Göttingen in 2018. Christoph Doerrenbaecher, our discussant at EGOS in 2017, provided helpful guidance on an early draft, as did Annelien Gansemans, discussant at the 2017 ECPR Joint Sessions of Workshops. Aurélien Acquier and Valentina Carbone gave useful comments at the ESCP Europe seminar in January 2019. The anonymous reviewers and editor at ILR Review have provided invaluable guidance. We gratefully acknowledge funding by the Volkswagen Foundation for the project "Changes in the Governance of Garment Global Production Networks: Lead Firm, Supplier and Institutional Responses to the Rana Plaza Disaster" under the "European and Global Challenges Program." 
Using qualitative data comprising interviews with multiple respondents in 45 garment brands and retailers, and unions and other stakeholders, the authors analyze the emergence of the Action Collaboration Transformation (ACT) living wages initiative, asking how the interfirm coordination and firm-union cooperation demanded by a multifirm transnational industrial relations agreement (TIRA) developed. Synthesizing insights from the industrial relations and private governance literatures along with recent collective action theory, they identify a new pathway for the emergence of multi-firm TIRAs based on common group understandings, positive experiences of interaction and trust. The central finding is that existing unioninclusive governance initiatives provided a platform from which spillover effects developed, facilitating the formation of new TIRAs. The authors contribute a new mapping of labor governance approaches on the dimensions of inter-firm coordination and labor inclusiveness, foregrounding socialization dynamics as a basis for collective action, and problematizing the limited scalability of this mode of institutional emergence. 


\section{Spillover Effects Across Transnational Industrial Relations Agreements: The Potential and Limits of Collective Action in Global Supply Chains}

Social auditing, the dominant form of private labor governance in global supply chains since the 1990s, is now widely acknowledged to have major limitations. Transnational industrial relations agreements (TIRAs), defined as governance mechanisms in which unions and multinational corporations engage in joint regulation of labor standards through signing a mutual agreement, offer a potentially transformative new model of labor governance. Global union federations (GUFs) have a longstanding interest in drawing multinational corporations into negotiations over labor standards. Global framework agreements (GFAs) emerged in the late 1980s, with a small but steady stream of multinational firms in diverse sectors signing agreements with GUFs. More recently, multi-firm TIRAs bringing together multiple brands and unions have begun to feature prominently in the search for new governance solutions, particularly in the labor-intensive global garment industry. In 2013, the catastrophic Rana Plaza factory building collapse prompted the creation of the largest TIRA to date with over 200 garment brands and retailers signing the Accord on Fire and Building Safety in Bangladesh (hereafter "the Accord") with two GUFs. Two years later, 15 garment lead firms and the IndustriALL global union federation co-founded the Action Collaboration Transformation (ACT) initiative designed to secure living wages for workers in garment supply chains through industry collective bargaining and reformed purchasing practices. Unlike previous multi-firm TIRAs, ACT's formation was not precipitated by major loss of life or scandal. Using the case of ACT, we examine a new mode of TIRA emergence, highlighting the role of spillover effects across existing governance initiatives.

In order to situate our case, we present a new mapping of labor governance initiatives that captures two factors which are critical for improving labor standards in global supply chains - worker voice and inter-firm coordination - and use it to examine the dynamics of 
institutional emergence in relation to TIRAs. Extant literature has analyzed how firms' reputational concerns in the face of activist campaigns push them towards political settlements in the form of regulatory institutions whether within the firm (corporate social responsibility) or beyond it (e.g. multistakeholder initiatives). Multi-firm TIRAs present particular problems of institutional emergence, since they require both inter-firm coordination and firm-union engagement. Contestation involving both unions and social movements has therefore usually been necessary to push firms into multi-firm TIRAs. We draw on recent collective action and industrial relations theory to identify another route of TIRA formation that emphasizes socialization processes within existing initiatives through which common group understandings, positive experiences of cooperation and trust can develop.

We examine these arguments using the case of ACT, a multi-firm TIRA intended to address the problem of living wages in global garment supply chains. We adopt an inductive approach focused on the process through which firms became involved in the initiative using qualitative data comprising interviews with multiple respondents in 45 garment brands and retailers, as well as respondents from unions and other stakeholder groups. We make two contributions to the literature. First, our mapping of labor governance initiatives situates TIRAs in the broader debate on global labor governance, highlighting two dimensions along which governance institutions developed away from individual corporate codes of conduct: firm collective action and labor inclusiveness. Second, the nature of our case allows us to foreground underexplored dynamics in the formation of multi-firm TIRAs, namely the socialization dynamics across TIRAs or other labor-inclusive multistakeholder initiatives (MSIs) facilitating inter-firm coordination and firm-union engagement, thus potentially creating spillover effects. We also discuss the potential limits of this form of institutional emergence, particularly regarding questions of scalability. 


\section{Situating ACT as a multi-firm TIRA: Context, mapping and drivers}

The fragmentation of production processes as a result of economic globalization has undermined traditional forms of government-enforced labor regulation and led to a patchwork of different forms of regulation at multiple levels (Marginson 2016; Fransen and Burgoon 2017). These include corporate codes of conduct (CoCs), labeling and certification, multi-stakeholder initiatives (MSIs), GFAs, as well as transnational institution-led standards and guidelines such as ILO core labor standards and the OECD Guidelines for Multinational Enterprises (Berliner et al. 2015; Donaghey, Reinecke, Niforou, and Lawson 2014). Until recently, industrial relations institutions were relatively marginal amid the plethora of private regulatory initiatives. Indeed, early analyses of private governance systems warned of unions being "crowded out" of regulatory processes by NGOs (Compa 2001; O'Rourke 2003). But the signing of the Accord and several new GFAs underscores the growing importance of TIRAs, especially in the garment industry, not least because of their potential to promote joint liability for working conditions between brands and contracted factories (Anner, Bair, and Blasi 2013).

\section{Contextualizing ACT}

ACT was co-founded in 2015 by the IndustriALL global union and 15 leading garment brands and retailers all of which were either members of the Ethical Trading Initiative (ETI), a union-inclusive MSI, or the Accord (see Table 1). ACT aims to promote living wages by establishing industry collective bargaining in selected garment and textile producing countries supported by world class manufacturing standards and responsible purchasing practices. According to their memorandum of understanding (MOU) (ACT 2017), brands and IndustriALL will use their leverage with partners in target countries "to bring them together to negotiate towards a living wage," alongside "joint approaches to governments in support of 
higher minimum wage outcomes, including brand commitments to continued sourcing." Brands commit to "ensure that their purchasing practices facilitate the payment of a living wage ... [and to] ... support long-term partnerships with manufacturers in support of ethical trade" (ACT 2017). Signatories will together agree on target countries and country-specific action plans. ACT thus envisages multi-level industrial relations mechanisms, with IndustriALL negotiating with signatory brands regarding purchasing practices, IndustriALL and signatory brands encouraging industrial relations actors in garment-producing countries to the bargaining table, and local industrial relations actors negotiating industry-wide collective agreements.

Insert Table 1 about here

In terms of its substantive aim, ACT attempts to enact longstanding commitments regarding living wages contained in international instruments such as ILO Convention 131 and Recommendation 135 (for a detailed history of the ILO's approach to the living wage see Reynaud 2017), and implied by the UN Declaration on Human Rights (Article 25). The concept of the living wage has also been taken up by other private regulatory initiatives. For example, it is included in SA8000 (Standard 8) as well as the ETI Base Code, where it is defined as "enough to meet basic needs and to provide some discretionary income," which is also the formulation used by ACT with the added explicit stipulation "during legal working hour limits" (ACT 2017). Living wages have been a campaign focus for NGOs such as the Asia Floor Wage Alliance and the Fair Wage Network (Miller and Hohenegger 2016) as well as for GUFs. 
Regarding process, the MOU specifies an experimental approach in which signatories are allowed "the space to explore different solutions, make room for imperfection and continuously adapt ... strategies to ensure implementation of ... joint goals" (ACT 2017). Nevertheless, the stated aim of ACT is ambitious: to "transform" the global garment and textile industry (ACT 2018a). At the current stage of development, participating firms have analyzed their purchasing practices and agreed a new set of purchasing principles, while negotiations are ongoing regarding an industry collective bargaining agreement in the first target country, Cambodia. The proposed sequencing is simultaneous; brands will implement the changes to their purchasing practices and make the country "a preferred destination for sourcing and investment for a defined period of time" (ACT 2018b) once the collective bargaining agreement is concluded. Although ACT is not legally binding, it does have a grievance mechanism (both internal and external), and envisages third party monitoring of brands' sourcing volumes. In addition to Cambodia, other target countries include Bangladesh, Myanmar, Turkey and Vietnam.

The far-reaching changes envisaged by ACT will take time, and currently the outcomes are uncertain. They depend not only on the willingness and determination of the participants, but on multiple stakeholders in target countries. For example, target country states will need to ensure enabling regulation such as freedom of association and right to collective bargaining (ACT, 2018b). In this article, however, our interest is in the processes underlying ACT's emergence.

\section{Mapping private labor governance initiatives}

None of the extant typologies of corporate social responsibility (CSR) or global labor governance initiatives (e.g. Donaghey and Reinecke 2018; Fransen 2012b; O’Rourke 2006) fully delineate the emerging space of multi-firm TIRAs. To specify our terms, by TIRA we 
mean that organized labor-local and/or global—is included in devising and implementing an agreement signed by the union(s) and one or more lead firm(s). Building on Helfen and Fichter's (2013: 553) definition of GFAs, TIRAs are "the negotiated result of interest representation ... for the pursuit of global labor relations by defining the content, selecting the actors, delineating the processes and setting the boundaries of labour-management interaction." As with other forms of private governance, TIRAs can involve just a single firm, as in the case of GFAs, or multiple firms, as in the case of the Accord or ACT. TIRAs can involve global as well as national-level unions. The growing importance of TIRAs - both single-firm and multi-firm - highlights the need for a mapping that distinguishes the dimensions of union inclusion and multi-firm coordination.

Multi-firm coordination is important because collective action problems lie at the heart of poor labor standards in global supply chains with the diversity of interests of lead firms paralleled by the conflicting interests of suppliers (Locke 2013). Multi-firm initiatives potentially have the scale to address such barriers to raising labor standards by placing limits on the race to the bottom. Union inclusion, meanwhile, is salient as a means of increasing the output and input legitimacy of labor governance initiatives (Donaghey and Reinecke 2018). It can also, via collective bargaining, potentially increase the scope of firms' interventions, as well as providing an inbuilt monitoring mechanism via local unions where these exist.

Existing classifications of private labor governance initiatives typically do not explicitly focus on union inclusivity. Fransen (2012b), for instance, measures the stringency of private labor regulatory organizations by the scope of labor standards, implementation specificity and the degree of societal control, but does distinguish NGOs and trade unions in his conception of societal control. His analysis does not include GFAs and other forms of firm-union agreement regarding, for example, freedom of association or remediation (Blasi and Bair 2019). Similarly, O’Rourke (2006: 19-20) distinguishes between what he calls 
privatized, collaborative, and socialized regulation. Union inclusiveness is not an explicit feature of this distinction since, for example, the ETI and Fair Wear Foundation (FWF), both union-inclusive MSIs, are classified as forms of collaborative regulation and socialized regulation respectively. Union inclusion likely did not emerge as a specific dimension in earlier analyses since key campaigning organizations such as the Clean Clothes Campaign (CCC) include both unions and NGOs, while barriers to unionization mean the union/NGO distinction is sometimes porous in producer countries.

More recently, Donaghey and colleagues (2014) contrasted labor power with consumer power, explicitly drawing attention to the role of labor in private governance initiatives, but their classification is intended to highlight governance gaps rather than categorize private governance arrangements. Donaghey and Reinecke (2018) distinguish union voice as a dimension in their categorization of global labor governance under the two headings Corporate Social Responsibility and Industrial Democracy, spelling out its significance. We build on this distinction, adding the dimension of single-firm versus multifirm forms of governance, which, although already prefigured in the private governance literature where researchers have analyzed the movement from unilateral CSR to MSIs (e.g. Bartley 2007), has been less emphasized in relation to TIRAs, most likely since multi-firm TIRAs have only recently emerged.

Figure 1 maps transnational private labor governance initiatives on the dimensions of union inclusiveness and inter-firm coordination. Our mapping highlights the theoretical and empirical distinctiveness of multi-firm, union-inclusive initiatives which require a double form of coordination: between firms and between firms and unions. As we outline below, drawing on the industrial relations literature, these two processes are interrelated but discrete (e.g. Behrens 2004; Offe and Wiesenthal 1980; Schmitter and Streeck 1999; Traxler 2004). 
Insert Figure 1 about here

\section{Drivers of institutional emergence across private labor governance initiatives}

Both the private governance and industrial relations literatures have examined the drivers of different labor governance initiatives. Whereas the private governance literature has largely focused on explaining CoCs, business-led initiatives and MSIs (quadrants I and II), the industrial relations literature has concentrated on quadrant III, notably GFAs. Yet to explain the emergence of initiatives in quadrant IV, we need both streams of literature, in addition to industrial relations theory concerning employers' organization which highlights inter-firm coordination as a distinct process.

Private labor governance in the form of CoCs (quadrant I) was developed by brands such as Levi's and Nike in the early 1990s in response to activist pressure. Locke and colleagues have provided detailed analyses of the form and limitations of such regulation (e.g. Locke, Amengual and Mangla 2009). In terms of institutional emergence, the intersection of activist and union campaigns with firms' interest in reputation preservation was crucial (see, for example, Merk 2011 in relation to Nike). The literature suggests that certain characteristics render some firms more visible and prone to activist targeting than others. Reputation-sensitive firms are more receptive to activist pressure (Bartley and Child 2014) and are liable to adopt stricter forms of regulation (Fransen 2012b). Such firms were thus the leaders in CoC adoption and development.

Bartley (2007) provided a detailed account of how firms moved from unilateral CoCs to involvement in MSIs (quadrant II). Given that any one firm's wrongdoing could damage 
the industry's shared reputation, or "reputation commons" (e.g. Barnett and Hoffman 2008), firms faced a collective problem of reputation preservation. Nonetheless, they proved unable to cooperate with each other to create a "club good" (Prakash and Potoski 2007) of shared reputation. They only did so when faced with political contestation from NGOs and social movements, the outcome of which were private settlements facilitated by states in the form of MSIs (Bartley 2007). While political contestation and reputational concerns provided the motor for MSI development, their diffusion has also been aided by overlapping organizational membership and institutional linkages (Bitzer et al. 2012), the emergence of transnational communities of practice (Bartley and Smith 2010), and the dissemination of norms (Dingwerth and Pattberg 2009). The driver of such diffusion has been social interaction among different policy makers that lead to information-sharing, norm constitution and coordination (e.g. Fransen, Schalk and Auld 2016; Eberlein et al. 2014).

In terms of our mapping, industry-led associations and MSIs necessarily entail firm collective organization, but differ in terms of union inclusion. Fransen (2012a), for instance, shows how firms in countries such as Germany eventually eschewed MSIs in favor of the BSCI, a business-led initiative focused on labor and environmental standards (Egels-Zandén and Wahlqvist 2006). By contrast, unions assumed an important role in the ETI, which has a tripartite - firm, union, NGO - governance structure. Union-inclusive MSIs fall between quadrants II and IV since, though integrating unions, they are not constituted as firm-union agreements in the form specified by Helfen and Fichter (2013).

Turning to the emergence of initiatives in quadrant III, explanations follow similar lines to the literature on MSIs. For example, Papadakis (2011) groups the drivers of GFA negotiation under the headings coercive, anticipatory, and civil society pressures. Regulatory or cultural factors associated with the country of origin are referred to as "coercive" drivers. "Anticipatory" pressure refers to firms' need to maintain reputation which, in combination 
with civil society pressure, aligns with the account in the private governance literature. Such pressures can be intensified by focusing events that shine a light on bad practice (Schuessler, Frenkel and Wright, 2019). The first GFA in the global garment industry signed by Inditex in 2007, for instance, was triggered by the Spectrum factory collapse in Bangladesh in 2005. The painstaking work involved in establishing a relief scheme for the victims helped forge a relationship between the International Textile Garment and Leather Workers Federation (ITGLWF) and Inditex (Miller 2011). Papadakis (2011: 67) accordingly notes that interpersonal relations between leading personnel in multi-national companies and GUFs have, in some cases, been an important facilitator of GFAs (see also Helfen and Fichter, 2013).

Our mapping highlights a gap in the institutional emergence literature relating to the distinct features of quadrant IV. Initiatives in this quadrant are constituted by two processes inter-firm coordination, and the establishment of firm-union relations. The extant global labor governance literature does not explicitly separate out these two processes. They are, however, clearly distinguished in industrial relations theory regarding employers' organization. This literature is relevant because, while lead firms do not directly employ workers in their supply chains, they have been progressively forced to accept responsibility for them through the processes noted above (Helfen, Schüßler, and Sydow 2018). Industrial relations scholars have identified two main motives for the emergence of employers' associations. Organization is frequently a defensive move compelled by union strength or state policies (Offe and Wiesenthal 1980; Schmitter and Streeck 1999; Traxler 1999). Such organization helps employers to achieve wage restraint in the face of assertive unions (Traxler 2004). Yet employers also organize in order to provide collective goods (Behrens 2004). For example, employers' organization can prevent undercutting by competitors, enhancing firms' ability to 
maintain a productive workforce through "best practice" employment conditions and to secure industrial peace (Brown 2008; Streeck 1987).

Examining the literature more closely in conjunction with wider collective action theory, there are two issues here: the motivation for collective action, and the mechanisms through which it can be achieved. In the case of pressures from unions and/or the state, the motive and mechanism for employer organization are fused but, as famously identified by Olson (1965), this does not apply to the provision of collective goods which he sees as requiring coercion or special incentives. Another route, however, is highlighted by Ostrom's (2000) review of experimental and field research where she shows that collective action can be facilitated by certain conditions such as face-to-face interaction, past experience, the presence of a common group understanding and trust.

The issues involved in firm-union engagement are similar. Employers are often assumed to want to avoid negotiating with trade unions and, where such engagement is unavoidable, to prefer to negotiate as a single employer rather than to delegate autonomy to an employers' association (Schmitter and Streeck 1999: 38). But, once established, firmunion relations can extend the ability of employers to secure collective goods such as industrial peace. For example, Behrens and Helfen (2016) argue that the firm-union coordination and employer organization entailed in German "social partnership" is sustained by a history of positive interactions engendering a shared normative orientation and belief in the capacity of coordination to resolve conflicts.

While the contentious actions of campaigners and NGOs have been crucial in driving firms towards engagement in quadrants I and II, such campaigns have rarely been sufficient to secure firm collective action and firm-union coordination in quadrants III and IV without the additional momentum created by focusing events. For example, the impetus required for 
the conclusion of the Indonesia Freedom of Association Protocol (Siegmann, Merk and Knorringa 2016) was only generated by the release of a critical report in the run-up to the 2008 Beijing Olympic Games denouncing violations of freedom of association and the right to collective bargaining in sportswear supply chains (Gardener 2012). The Accord, meanwhile, only started attracting corporate signatories after the Rana Plaza disaster when GUFs, allied with social movement organizations, secured the requisite global attention to shame significant numbers of firms into action (Reinecke and Donaghey 2015). In the case of the Accord, the dynamics described by Bartley (2007) in relation to MSIs clearly apply member firms were (initially at least) organized by GUFs, NGOs and campaigners who corralled them into signing the agreement.

Yet, the conditions identified by Ostrom (2000) suggest an alternative route to interfirm collective organization and firm-union coordination, highlighting the importance of face-to-face relations, common understandings and trust. Meanwhile, Behrens and Helfen (2016) show how positive experiences of collaboration can help consolidate or sustain interfirm and firm-union interactions. These dynamics may develop at the interface of different initiatives, which our mapping allows us to analyze. For instance, Reinecke and Donaghey (2015) refer to relational dynamics, noting that GUFs leveraged relationships built with GFA brands such as Inditex to convince them to sign the Accord. This potentially indicates a positive interplay between quadrants III and IV. More generally, relations developed within one quadrant can facilitate the emergence of initiatives in another. Institutions supportive of collective action may then be crucial for the stabilization and growth of such initiatives (cf. Locke 2013: 16). In sum, echoing findings regarding the drivers of collective firm-union engagement in (sub-)national contexts, firms' collective engagement with GUFs has usually developed in response to contestation amplified by a focusing event. Analyzing a case which did not follow this pattern, we draw on more recent collective action theory highlighting the 
role of common understandings and trust as facilitators of inter-firm coordination and firmunion engagement in the form of TIRAs. In doing so, we highlight a spillover effect through which relations within TIRAs and union-inclusive MSIs can facilitate the emergence of new union-inclusive initiatives.

\section{Data and Methods}

In order to understand the drivers of inter-firm and firm-union coordination in the case of ACT, we draw on a large qualitative dataset. The primary data source is 29 interviews with representatives of 13 ACT founding brands and retailers across multiple countries. While we approached all 15 ACT founders, two firms declined our interview request. In addition, to augment our understanding of the dynamics of emergence, we considered the behavior and perspectives of a selection of firms sharing similar characteristics to ACT founders that have not (yet) joined ACT. Since the majority of ACT founders are based in the UK or in Germany, we selected firms from these countries that shared similar characteristics to ACT founders (20 interviews with 13 UK-based non-ACT firms and 40 interviews with 19 German non-ACT firms). These interviews provided external perspectives on ACT, and are used to support our analysis of recruitment to ACT from the ranks of ETI. We also conducted 10 interviews with representatives of 7 union organizations ( 2 global, 1 British, 4 German) and 14 interviews with 12 stakeholder organizations that we identified as active participants in debates and initiatives in the field of transnational labor governance, including representatives of intergovernmental organizations, journalists, NGOs, importers, business associations and government agencies. Using semi-structured interview guides, we explored topics such as labor standards policies, supplier relations, and reactions to the Rana Plaza disaster including questions about the Accord and ACT. All interviews were tape recorded and transcribed. German language interviews were translated into English. 
Interview data was complemented by 17 informal talks with knowledgeable informants (unions, NGOs, legal experts, business associations, consultants, firm representatives). We also participated and/or observed 52 industry events where labor standards in garment supply chains were discussed, recording data from observation and informal talks in detailed field notes. In addition, we drew on numerous sources of secondary data to gain a better understanding of firms' behavior, including membership lists of labor standards initiatives and company-generated materials, such as websites and reports.

Analysis proceeded in two stages. First, we considered structural characteristics of ACT founding firms in relation to non-ACT members of similar size. This involved analyzing secondary data collected on ACT founders and comparable non-ACT firms to identify possible patterns in firm characteristics and behaviors. Second, after ruling out any clear structural drivers, we systematically analyzed interview transcripts and field notes using the qualitative data analysis software NVivo. Moving iteratively between theory and data, we sought to develop a theoretically-informed account of how ACT emerged. First, we looked for dynamics of contestation and coercion as outlined by extant literature. However, as we outline below, living wage campaigns, while significant, did not place unavoidable pressure on ACT founder firms to organize. Second, we coded firms' accounts of their involvement in ACT, which could be grouped under two broad headings: inter-firm relations and firm-union relations. We coded descriptions of contexts in which these relations were formed, as well as the nature of the relationships. This enabled us to develop a timeline of ACT formation, including the key contexts in which the relations underlying it had been formed. In terms of the nature of the inter-firm and firm-union relations underlying ACT, our coding revealed the importance of face-to-face relations, common group understandings and trust. This led us to revisit industrial relations theory regarding employers' associations and collective action literature, enabling us to theorize our inductive findings. 


\section{Contestation and reputational pressure: The politics of living wages}

In the past, firms have been pushed into TIRAs in the wake of focusing events. While the Accord played an important role in the development of ACT, as we show below the initiative was not a direct response to Rana Plaza, or any other event. This perspective is supported by the reflections of respondents from ACT founders:

Interviewer: Do you think you need a focusing event such as Rana Plaza [to make progress on labor standards]?

Respondent: No.

Interviewer: You don't?

Respondent: No... And ACT is an example of that. They're not waiting for campaign groups to say you've done nothing on living wages for the last 10 years. $(11 / 03 / 16 / \mathrm{ACT} 01 / \mathrm{R} 1)^{1}$

Accord was reactive... ... ACT is a proactive thing. We are trying to move things without facing bad things in the past. It's really a completely different approach. No brands, I feel, have been pushed. (09/18/18/ ACT02/R1)

Such accounts are confirmed by the sequence of ACT formation. Rather than being pressurized to sign the MOU, the brands developed "enabling principles" which they then took to IndustriALL. After further negotiations these formed the basis for the MOU. This narrative was confirmed by Jenny Holdcroft of IndustriALL (interviewed on the record), who provided the following description of the process:

\footnotetext{
${ }^{1}$ Interview codes contain the date of the interview, a number for each firm and a signifier for the respondent in the case of a formal interview (R1, R2) or a signifier for the source being an informal talk (IT).
} 
They [the brands] were already looking at that [the barriers to living wages] as a group, and we were aware of that, but we said "You carry on your discussions" - because we knew this was a big deal and it wasn't something that could be rushed - and we said, "When you're ready, come and talk to us about what it is that you're thinking of doing."

After about a year they came to us with a sheet of paper called the "Enabling Principles," which is what they'd discussed among themselves as being the key factors. It was about all of the stuff that you can now see in ACT. It's about collective bargaining, freedom of association, purchasing practices, and world class manufacturing. (03/08/17)

IndustriALL thus confirm that they were not putting firms under pressure to address the living wage issue immediately.

Does this "proactive" account of ACT formation tally with evidence regarding the politics of NGO living wage campaigns? Living wages have been the focus of longstanding campaigns by organizations such as the Asia Floor Wage Alliance and the CCC. Nevertheless, firms had developed arguments to deflect such campaigns, focused on contentiousness of calculating living wages and the collective action problem involved in one firm improving wages at suppliers shared with other firms. As a CSR officer of an ACT founder conceded:

We've been very good at saying we want to do something on wages. And then what we'll do is say, "Oh the NGOs have got an equation, the unions want collective bargaining, etc." And whilst those two key stakeholders were, let's say, arguing it out, the brand is more than comfortable to sit back and say, "Well, there's no figure."... I mean ridiculous, absolutely ridiculous 
argument, but it was brilliant, because for the brands there was no real pressure. $(10 / 06 / 16 / \mathrm{ACT} 04 / \mathrm{R} 1)$

The second potent argument in brands' defensive armory against living wages has been that unilateral action on wages is futile. The case is eloquently put by a CSR officer of a founding member of ACT:

You can't guarantee living wages within a factory unless you have $100 \%$ of the factory's capacity, $100 \%$ of the time. That just doesn't happen. And some suppliers are split out into sheds on the same site. You can't pay workers who are working for one brand in one shed or factory hall, a different pay rate to those in the other, because they talk to each other. There'd be strikes, and rightly so [laughs]. (02/14/17/ACT05/R1)

Such arguments regarding the infeasibility of the living wage meant that, as the respondent above noted, many brands experienced "no real pressure" to act on living wages.

Nevertheless, as the behemoth of the garment industry, H\&M has been the focus of targeted campaigning efforts. In September 2012 the CCC in collaboration with the Cambodian trade union C.CAWDU launched "No more Excuses," a European-wide campaign highlighting the gulf between the minimum wage paid to workers producing for H\&M in Cambodia and the living wage, and demanding improvements (CCC 2012). The next month a well-known Swedish documentary program "Kalla Fakta" (Cold Facts) focused on the issue, repeating the CCC's assertion that workers producing for H\&M in Cambodia were paid less than $25 \%$ of a living wage (Sowray 2012). Facing globally-reported negative publicity on its home turf, and a sustained activist campaign, H\&M needed to respond. 
It did so a year later in October 2013, issuing its "living wage roadmap" that stated that strategic suppliers should have pay structures in place to pay a fair living wage by 2018 , a change in policy it estimated would reach "around 850,000 textile workers" (Turnaroundhm.org 2018). ${ }^{2}$ The initial idea was to trial the "fair wage method" developed by ILO expert Daniel Vaughan-Whitehead (2010) at one Cambodian and two Bangladeshi factories where H\&M would buy $100 \%$ of the factories' product before expanding the program to cover all factory workers producing for H\&M. The policy was supported by an advisory board, which included IndustriALL as well as the ILO and the Workers' Rights Consortium.

In producing its roadmap, $H \& M$ acted to preserve its reputation in the face of political contestation. Its success in doing so was evident in the headlines generated in October 2013 which were the reverse of those the October before. H\&M was now presented as a corporate leader in the field of living wages rather than a laggard. But even as it launched its campaign, $\mathrm{H} \& \mathrm{M}$ cautioned that it would be unable to transform the industry on its own arguing, "We believe that the wage development in production countries, which is often driven by governments, is taking too long. H\&M wants to take further action and encourage the whole industry to follow" (Farrell 2013). It therefore began working with other brands, as evidenced by a multi-brand intervention in Cambodia in 2014 weeks before an anticipated government decision on raising the minimum wage. In an important precursor to the formation of ACT, a

\footnotetext{
${ }^{2} \mathrm{H} \& \mathrm{M}$ have now removed material regarding the 2013 living wage roadmap from their website, but the campaigning organization Turnaroundhm.org, an alliance of the CCC and International Labour Rights Forum, have archived relevant material including contemporaneous press reports in Turnaroundhm.org (2018). There is no doubt that the pledge was made.
} 
day after a GUF-organized Global Day of Action calling for minimum wage rises, eight major brands and retailers, (C\&A, H\&M, Inditex, Primark, Next, New Look, N Brown Group, and Tchibo) wrote to the Cambodian government and the Garment Manufacturers Association in Cambodia (GMAC) pledging that they would pay more for Cambodian-made garments if workers were to be paid more (Oka 2018). The firms involved in this action all subsequently became ACT founders.

Reputational concerns were clearly part of the motivation for such efforts - living wages were a demand that dogged the industry, with tales of low-paid workers frequently surfacing to tarnish its image. But aside from the giants H\&M and Inditex, the firms that chose to join ACT were no more vulnerable to such pressure than the larger numbers which did not. Indeed, as ACT founders noted there was "no real pressure" on most of them to address the living wage issue; they had developed arguments to deflect the campaigns. How then did a particular group of companies come together to form ACT and to cooperate with IndustriALL? Below we examine this question, first analyzing how the basis for firm collective action developed, and then examining how relations with IndustriALL emerged.

\section{“Befriended companies:" How inter-firm commitment to ACT was secured}

In our analysis two union-inclusive institutions emerged as central to building inter-firm cooperation: the ETI and the Accord. Relations within these organizations facilitated the emergence of a common group understanding underlying the emergence of ACT.

Brands and IndustriALL concur that the idea of ACT originated in discussions held within the ETI. Jenny Holdcroft of IndustriALL reported, "It really grew out of discussions in the ETI around living wages and a group of brands ... discussing 'How can we make more of a collective effort on this?' in light of the futility of trying to take an individual brand approach to wages in their own factories" (03/08/17). Likewise, a CSR officer heavily 
involved in the foundation of ACT argued, "The thing that brought the core group together was ETI membership, because as ETI members, we meet regularly ... we're a community I guess, and we don't see ethical trading as a competitive arena" (02/14/17/ACT05/R1). The same respondent described ETI members struggling with the fact that, while living wages form part of the ETI base code that members are supposed to uphold, even the largest brands had failed to make progress on this:

In all our codes of conduct, we have got living wages.... None of us deliver living wages, so [breaks off]..... In reality, we work on getting our suppliers to comply with legal minimum wages [emphasis in original], so we are all misaligned with our goals and our code of conduct. So: big difficulty. And there are brands who are members who have been doing some piloting work of their own in these areas.... a couple of the biggest apparel manufacturers in the world found it a real challenge. (02/14/17/ACT05/R1)

Quotations such as this reveal the sense of frustration, but also emerging common purpose, which developed within the ETI living wages discussions. That is, they show the existence of a common group understanding among the initial core of ACT founders who were ETI members. This accounts for the dominance of ETI members among ACT founders (12/15) highlighted by Table 1, as well as for the preponderance of UK brands in ACT, since ETI is a UK-based institution. In relation to spillover effects, the quotations also demonstrate the centrality of ETI as a facilitating institution in the early stages of ACT formation. Nevertheless, it should be stressed that ACT founder firms did not feel able to achieve their objectives within ETI, which led them to establish a TIRA.

The second stage in ACT's emergence was the deepening of inter-personal relationships and trust. Again, both IndustriALL and corporate respondents concur that this 
process was facilitated by collaboration within the Accord of which 12 out of 15 ACT founders were signatories (see Table 1). The development of the relationships between brands within the Accord is well captured by the following account of the CSR manager of an ACT founder:

We started to talk about wages in the corporate group [of the ETI] and I think a year later, when the Accord started, we all got to know each other a bit better, so the idea arose "okay, we can actually think so far and maybe even work together on wages." And from this process, a number of groups of companies were created, that - I would now call ourselves "befriended companies" - where there is a relationship of trust on a personal level or has arisen over the years that one knows that one is thinking similarly regarding such strategic initiatives. (12/02/16/ACT06/R1)

This quotation reveals the multi-level nature of the process. An institutional outcome - the creation of a group of "befriended companies" - was facilitated by the micro-level development of "a relationship of trust on a personal level."

The other dimension of the relationships fostered was "the confidence that came with the Accord" (12/02/16/ACT06/R1), which showed the potential of collective agency. As a representative of an ACT founder elaborated at a public event:

I think what the Accord has done for all of us involved is shown what can be achieved now, and as we start to build examples like the Accord that have been successful we get more confidence and courage to try something different. And for us, really, it has meant looking at starting to look at wages, so through the ACT collaboration. (11/16/16/ACT07/R1) 
Inter-firm relations were thus cemented through a collective endeavor which fostered strong face-to-face relations between influential individuals, and also created a sense of possibility that companies could "dream and talk about things [such] as living wage[s]" (03/05/19/ACT08/R1). That is, trust, a successful experience of interaction, and common group understandings were all achieved within the framework of the Accord.

Initial participation in the facilitating environments of the ETI and the Accord helped develop the inter-firm relations underlying ACT. But far from all ETI and Accord members joined ACT, while one non-ETI ACT member firm was only linked to the Accord via its parent company. Again the explanation for this lies in personal relationships. The following quotation from a recruiting sergeant for ACT illustrates the process. The initial core of ACT brands decided that they wanted members with a mix of characteristics and then recruited through personal approaches. As our respondent explained:

I chose four people, and the reason why I chose four is because I know them individually ... so I knew what they would do.... And it's not about the brand ... it's about the individual, because that's what makes a difference. So you see, not about the brand at all. Honestly.... Specifically, every one of those was hand-picked.... I needed people who would understand the bigger picture.... They are the CSR whatever, etc. But on an individual level they have passion, commitment, understanding. (10/06/16/ACT04/R1)

Again, trust and face-to-face relations are key - this respondent recruited CSR officers on the basis of personal trust and anticipated commitment to the project. Brand and personal relations were thus intertwined in the formation of ACT, with formal relationships between brands within institutions such as the ETI and the Accord infused with informal content - 
"trust on a personal level" - and relations between individuals such as those outlined in the quotation above formalized within an institutional commitment.

While personal relations were able to cement a committed core group of ACT members and to avoid diluting or inhibiting progress, initial recruitment through personal relationships may have also limited the initiative's growth. Indeed, the close-knit character of ACT seems to have been off-putting to some outside the inner circle. As one CSR officer from a large UK-based firm within the ETI which did not join ACT, reported:

It's a strange one. It's like you want to say "yes" [to joining ACT] but there is something to do with how it's being controlled which isn't making it feel comfortable.... If ... it went to everybody, maybe through a neutral platform like the ETI or something and it said, "This is what this is going to look like," then I think that would be far more attractive to a much wider collection of brands. But that wasn't how it was done. And it was also done with who knows who? ... I don't know, it just got a bit funny. (09/20/16/NONACT01/R1)

Some other potential recruits appear to be waiting for "proof of concept" - some tangible outcomes from ACT - before committing. As the CSR officer of another large UK firm reported:

We're still kind of waiting for what it will deliver and so for us we wanted to join when ... [there's] something to implement in a supply chain and work on.... Collaboration, particularly between brands and businesses, is really difficult, so I think it's good intention; what will come of it, I don't know at the moment, I can't quite see that. (10/04/17/NON-ACT02/R1) 
That neither of these brands - both ETI members - have ruled out joining ACT in the future, supports our account of ACT's formation. We do not believe that the failure of some highprofile ETI members to join ACT undermines our point that ETI provided an enabling environment for ACT formation. Rather, ACT's currently limited membership supports our argument regarding the importance of face-to-face relationships in its formation, which, while supporting institutional emergence, may have also been a factor in restricting growth after the formation stage. Once the purpose was set, ACT was ready to expand, but has been initially faced with the forms of skepticism expressed in the quotations above. This presents a chicken and egg problem. For instance, the Cambodian employers' association GMAC - on which ACT's first intervention depends - wants a greater proportion of buyers to join ACT before committing to an industry collective bargaining agreement (12/11/18/ACT08/IT). Meanwhile, without evidence of a successful pilot, ACT is struggling to recruit further firms.

\section{Shared interests: Explaining firms' willingness to engage with unions}

The formation of a multi-firm TIRA requires not only inter-firm organization but also relations with trade unions. The other crucial element in ACT's formation was thus the development of relationships between member brands and IndustriALL. We argue that this relationship was underpinned by a shared interest in a long-term approach to the living wage issue. Nevertheless, as in the case of inter-firm cooperation, the formation of institutional links and personal relations of trust was necessary to facilitate the birth of a multi-firm TIRA.

As noted above, firms have claimed that an industry-wide approach is needed to deliver living wages. The collective action problems facing firms are that they risk becoming uncompetitive on price if they unilaterally pay suppliers more in order to raise wages and that, even for firms able to bear additional costs, it is difficult to improve wages when multiple lead firms share suppliers. Even a subset of firms working together cannot address 
this problem without a mechanism to extend living wages across an industry. Such a mechanism is potentially provided by industry collective bargaining, which in turn depends on IndustriALL's affiliates. That is, cooperation with IndustriALL increases the potential scope of the initiative.

Another attraction of IndustriALL from brands' perspective was that they were prepared to be patient in order to achieve their long-term goal of establishing a functioning industrial relations architecture in producer countries, including union recognition and the development of industry collective bargaining. They were therefore less insistent than NGOs regarding the immediate provision of living wages. Jenny Holdcroft of IndustriALL, acknowledging that action on living wages was "very, very difficult" and required a systematic long-term approach, cautioned:

It would be ridiculous for me to set deadlines at this point and say "At this time we'll have achieved this" because it's bigger than that; it's a huge thing. It's transformation of the industry... We're not pretending that any of this is going to be delivered on soon. $(03 / 08 / 17)$

Such long-term time horizons suited brands and made IndustriALL a more attractive partner in developing approaches to living wages than NGOs which were demanding urgent action. The ACT approach was potentially transformative, but also, as can be seen in the following quotation from a large ACT founder, eased the immediate pressure unilaterally to raise wages by a specified amount:

Figures [for a living wage] is something that we as brands...we're not interested. We will pay whatever has been decided, but it is not up to us to decide, you know, what is the figure in a country. The figure in a country has to be decided by the actors in the country. And what we say is...yeah, I mean 
the most mature way we know about doing that is through a collective bargaining, so let's put the playground correct for them to work and to create the scenario that they want to see and, you know, let's agree upon the collective bargaining and as an outcome we will, you know, we will act accordingly. (04/24/18/ACT01/R2)

Acting "accordingly" at the present stage entails abiding by negotiated sourcing commitments once an industry-level collective bargaining agreement is concluded, as well as ensuring suppliers pay at the level stipulated in the agreement (ACT 2018b). IndustriALL's long-term interest in building up unions and collective bargaining institutions in producer countries thus offered brands a way out of their collective action problem, while also providing a response to living wage campaigners.

Nevertheless, it is a big jump from a theoretical coincidence of interests - which had existed prior to ACT - to firms' decisions to partner with IndustriALL in a joint initiative. Prior to the Accord only one ACT founder, Inditex, had signed a GFA for its production division, while H\&M had concluded a GFA with another GUF, UNI, for its retail division, and had invited IndustriALL onto their advisory board regarding living wages for production workers. But unions were still regarded skeptically by many in the industry. In order to explain the emergence of ACT, we have to understand the development of institutional and personal relations with IndustriALL within union-inclusive institutions. Inditex had the most longstanding relationship with IndustriALL, having signed a GFA in 2007. One of their representatives called ACT an "opportunity to reinforce and build on what we are already doing around living wages with the Global Framework Agreement with IndustriALL" (Shift 2018). Other firms developed relations with IndustriALL later. The ETI provided some exposure to IndustriALL, but for many ACT firms it was participation in the Accord which changed their perspective on unions. 
As noted above, the ETI brought brands together as "a community" (02/14/17/ACT05/R1), providing a safe space in which interpersonal relationships could develop and potential solutions to industry problems could be discussed. Notably as a tripartite initiative governed by firms, NGOs and unions, union-inclusive solutions to issues were perceived as legitimate and even desirable within the ETI. It also provided member brands with an awareness of IndustriALL, albeit not the experience of negotiation showcased within the Accord.

The Accord promoted trust and deepened key relationships between brands and IndustriALL. Jenny Holdcroft argued that the Accord had raised her organization's profile among brands, concluding "we wouldn't have the ACT initiative without the experience of the Accord and what that has delivered to people" (03/08/17). Brands were even more emphatic on this point. One CSR officer, describing the process of ACT formation, put it succinctly: "What did the Accord do? It allowed us to build the relationships with IndustriALL. It allowed us to have the trust" (10/06/16/ACT04/R1). Another CSR manager from the same company described the process in more detail:

Once the Accord started to get going, the relationship with IndustriALL, the international trade union, became much more mature than anything that had happened before.... So we all had a beer one night. There was about seven or eight, and we said, "This is really good, so let's look at the opportunity to try to do something in a much more objective way." So a few of us, three or four of us, went over to meet with IndustriALL and we said, "We've got something we want to talk to you about." We said we're constantly challenged over the paradox of living wage.... We said "We need your help because you've got the intellectual background behind it as well." So that was how ACT came about. (10/06/17/ACT04/R2) 
The Accord thus transformed firms' relations with IndustriALL. One CSR officer described being "very against the whole Accord when we started it. We were a little bit forced into that whole set-up," but conceded "I think I really learned quickly that I had the wrong understanding of what the union are and how they work internationally" (03/05/19/ACT08/R1). Several ACT founders named particular IndustriALL officers with whom they had developed relations of trust, crediting them with pragmatism, creativity and expertise.

Thus, as in the case of inter-firm organization, face-to-face relations of trust and experience of successful collective endeavor were central to the formation of firm-union relations required for the development of ACT. Crucially, these relations developed within union-inclusive governance arrangements, highlighting the importance of the distinction introduced in our typology. Face-to-face relations influenced the formation of formal relationships between organizations - between brands, and between brands and IndustriALL - while these personal relationships were facilitated within union-inclusive governance arrangements, most importantly the ETI and the Accord.

\section{Discussion and Conclusion}

We proposed a mapping of labor governance initiatives along the dimensions of union inclusivity and firm collective action, highlighting the emergence of multi-firm TIRAs as a new form of labor governance, particularly in the garment industry. Multi-firm TIRAs require the development of inter-firm coordination as well as a willingness to engage with trade unions. We examined the case of ACT which exemplifies a new pathway of TIRA emergence. In contrast to earlier multi-firm TIRAs, the formation of which depended on pressure generated by focusing events and contestation, the firm coordination and firm-union 
engagement underpinning ACT were facilitated by trust and common group understandings built up within other union-inclusive initiatives, thus constituting spillover effects.

The trust and understanding that allowed firms to become "befriended companies" was generated within the ETI and the Accord. Within these institutions key individuals developed "trust on a personal level" which served to cement an institutional relationship between their firms. Common understanding was forged within the ETI living wages group, as firms grappled with the seeming impossibility of delivering living wages within extant business models. From these interactions emerged a group of leading firms willing to experiment and be in the "driving seat" of change. These exemplify the role of face-to-face interaction and trust emphasized by Ostrom (2000), the emergence of shared normative orientations forged by positive interactions highlighted by Behrens and Helfen (2016) in a national context, and also parallel discussions regarding spillover dynamics within fair trade and private governance initiatives via the creation of communities of practice (e.g. Bartley and Smith 2010).

The key question about inter-firm coordination emerging through face-to-face relations is its scalability. The mechanism can allow a small group of companies sharing a vision to organize, but how can other firms be induced to join them? In the case of ACT, the close-knit relations of the group seem to have been off-putting to some potential recruits. Meanwhile, many firms claim to be waiting for "proof of concept" before committing, which is difficult to provide when the Cambodia pilot is stalled by a lack of members. Two routes out of this potential impasse are suggested by the literature: first, a further round of contestation to push "laggard" firms to join (e.g. Bartley 2007) and, second, institutional support for ACT in producer and buyer countries (Locke 2013). Contestation from workers in target countries has recently begun with Cambodian unions calling out high-profile brands for failing to join ACT (IndustriALL 2019). Nevertheless, union campaigns often need to be 
supplemented by consumer power. GUFs can help harness this through international campaigning, but pushing large numbers of firms to coordinate may require an alliance of unions and social movement organizations (Reinecke and Donaghey 2015). For the moment, however, organizations such as $\mathrm{CCC}$ are continuing to pressure individual firms, notably H\&M, on living wages rather than encouraging firms to join ACT.

Locke (2013), drawing on industrial relations literature (e.g. Streeck 1987), emphasizes the potential of supportive institutions in solving collective action problems. Producer country governments are a necessary source of such support, particularly in relation to facilitating industry collective bargaining. But institutional facilitation in lead firm home countries is also important. Trade agreements have significant implications for the ACT model with, for example, the pending suspension of Cambodia from the EU's Everything but Arms trade regime over its record on democracy and human rights likely to impact ACT's first pilot. Elsewhere, there are some encouraging signs in relation to institutional support for ACT. For example, the UK Parliamentary Environmental Audit Committee recently endorsed ACT's approach (House of Commons Enviromental Audit Committee 2019), and the German Textile Partnership, a government-driven MSI, created a formal partnership with ACT. Such mechanisms could eventually bolster ACT's membership, though this remains unclear at the time of writing. Thus, while our research has identified a spillover mechanism whereby TIRAs can develop via socialization, scaling up likely requires additional mechanisms such as contestation and institutional support.

Although ACT faces problems of growth, its proposed mechanism does address another problem of scale. As Locke (2013) stresses, global supply chains are beset by collective action problems between lead firms and between the suppliers competing for their orders. By promoting industry bargaining in producer countries, ACT provides a means of addressing the collective action problem between suppliers who will be bound by the terms of 
industry collective bargaining, setting "a level playing field where competitive advantages cannot be won through substandard working conditions" (ACT 2018b).

The development of this potentially transformative solution was only possible because firms were willing to cooperate with IndustriALL whose affiliates must negotiate the collective bargaining agreements on which the ACT model depends. We argue the development of trust in IndustriALL occurred within the ETI and Accord, a union-inclusive MSI and multi-firm TIRA respectively. Positioned in our mapping as a bridge between the union inclusive and exclusive quadrants, the ETI's tripartite model normalized working with unions. The Accord took this to the next level, with leading firms experiencing negotiation with IndustriALL first-hand. As we have shown, the experience was a revelation.

We thus identify a spillover effect whereby firms involved in union-inclusive institutions such as the ETI, GFAs, and the Accord become more receptive to experimenting with further TIRAs, facilitated by the socialization in the space created by those arrangements. Likewise, involvement in ACT has already promoted the formation of further TIRAs, as several ACT members have now signed GFAs with IndustriALL: H\&M in 2015; Tchibo in 2016; ASOS in 2017 and Esprit in 2018. These developments, which are dynamic and non-linear, reflect firm learning regarding the capacity of unions to help resolve labor issues within global supply chains and the development of relationships which mean that IndustriALL is regarded as a trusted partner.

Since ACT founder firms had prior experience of union-inclusive governance arrangements, we have not provided evidence regarding mechanisms prompting movement from union-exclusive to the union-inclusive quadrants of our classification. In other cases such as the Accord this occurred through the pressure of a focusing event. But some firms, particularly those based in the US, have been resistant to union-inclusive institutions even in 
the face of such events - to which the formation of the Alliance for Bangladesh Worker Safety as a non-union, non-binding alternative to the Accord bears testimony (Donaghey and Reinecke 2018). Future research should examine the conditions under which new firms are drawn into union-inclusive arrangements, which at least partly seem to depend on different home country institutions (Helfen, Schüßler and Stevis, 2016).

Many questions remain. How do these dynamics play out in other industries? We have argued that the ETI, a union-inclusive MSI, played an important role in socializing firms into TIRAs, but as noted earlier Fransen (2012a) argued that firms could be socialized out of MSIs by stakeholder conflict. This raises questions regarding the other features of MSIs that encourage or inhibit firms' future participation in TIRAs. Meanwhile, the impact of TIRAs on working conditions is still unknown. It is also important to consider how global actors in these initiatives will interact with local actors (Zajak 2017). Many challenges lie ahead. Nevertheless, ACT founder firms took the two demanding steps required to create a multifirm TIRA: cooperating with each other and with unions. How they came to do so is the puzzle to which we have proposed an answer.

\section{References}

ACT. 2017. Memorandum of Understanding. Accessed at https://actonlivingwages.com/memorandum-of-understanding/ (December 2017).

ACT. 2018a. ACT Action Collaboration Transformation. Accessed at https://actonlivingwages.com/ (September 2018).

ACT. 2018b. Collective bargaining at industry level. Accessed at https://actonlivingwages.com/wp- 
content/uploads/2018/12/ACT_COMMS_Brief_Industry_Bargaining10.12.18-Web1.pdf (March 2019).

Anner, Mark, Jennifer Bair, and Jeremy Blasi. 2013. Toward joint liability in global supply chains: Addressing the root causes of labor violations in international subcontracting networks. Comparative Labor Law and Policy Journal 35(1): 1-44.

Barnett, Michael L., and Andrew J. Hoffman. 2008. Beyond corporate reputation: Managing reputational interdependence. Corporate Reputation Review 11(1): 1-9.

Bartley, Tim. 2007. Institutional emergence in an era of globalization: The rise of transnational private regulation of labor and environmental conditions. American Journal of Sociology 113(2): 297-351.

Bartley, Tim, and Curtis Child. 2014. Shaming the corporation: The social production of targets and the anti-sweatshop movement. American Sociological Review 79(4): 653679.

Bartley, Tim, and Shawna N. Smith. 2010. Communities of practice as cause and consequence of transnational governance: The evolution of social and environmental certification. In Marie-Laure Djelic and Sigrid Quack (Eds.) Transnational communities: Shaping global economic governance, pp. 347-374. Cambridge: Cambridge University Press.

Behrens, Martin. 2004. New forms of employers' collective interest representation? Industrielle Beziehungen/The German Journal of Industrial Relations, 77-91.

Behrens, Martin, and Markus Helfen. 2016. The foundations of social partnership. British Journal of Industrial Relations 54(2): 334-357. 
Berliner, Daniel, Anne R. Greenleaf, Milli Lake, Margaret Levi, and Jennifer Noveck. 2015. Governing global supply chains: What we know (and don't) about improving labor rights and working conditions. Annual Review of Law and Social Science 11: 193209.

Bitzer, Verena, Pieter Glasbergen, and Pieter Leroy. 2012. Partnerships of a feather flock together? An analysis of the emergence of networks of partnerships in the global cocoa sector. Global Networks 12: 355-374.

Blasi, Jeremy, and Jennifer Bair. 2019. An Analysis of Multiparty Bargaining Models for Global Supply Chains, Conditions of Work and Employment Series No. 105. Geneva: ILO.

Brown, William. 2008. The influence of product markets on industrial relations. In Paul Blyton, Nicolas Bacon, Jack Fiorito and Edmund Heery (Eds.), The SAGE Handbook of Industrial Relations, pp.113-128. London: SAGE publications.

Clean Clothes Campaign. 2012. H\&M under fire as Swedish television unearths Cambodian production scandal. Accessed at https://cleanclothes.org/news/2012/10/25/h-m-underfire-as-swedish-television-unearths-cambodian-production-scandal (September 2018).

Dingwerth, Klaus, and Philipp Pattberg. 2009. World politics and organizational fields: The case of transnational sustainability governance. European Journal of International Relations 15(4): 707-744.

Donaghey, Jimmy, and Juliane Reinecke. 2018. When industrial democracy meets corporate social responsibility_A comparison of the Bangladesh Accord and Alliance as a response to the Rana Plaza disaster. British Journal of Industrial Relations 56(1): 1442. 
Donaghey, Jimmy, Juliane Reinecke, Christina Niforou, and Ben Lawson. 2014. From employment relations to consumption relations: Balancing labor governance in global supply chains. Human Resource Management 53(2): 229-252.

Eberlein, Burkard, Kenneth W. Abbott, Julia Black, Errol Meidinger, and Stepan Wood. 2014. Transnational business governance interactions: Conceptualization and framework for analysis. Regulation and Governance 8(1): 1-21.

Egels-Zandén, Niklas, and Evelina Wahlqvist. 2007. Post-partnership strategies for defining corporate responsibility: The business social compliance initiative. Journal of Business Ethics 70(2), 175-189.

Farrell, Sean. 2013. H\&M pledges living wage for textile workers in Bangladesh and Cambodia. The Guardian November 25, 2013. Accessed at https://www.theguardian.com/business/2013/nov/25/h-m-living-wage-textile-workersbangladesh-cambodia (September 2018).

Fransen, Luc. 2012a. Multi-stakeholder governance and voluntary programme interactions: legitimation politics in the institutional design of corporate social responsibility. Socio-Economic Review 10(1): 163-192.

Fransen, Luc. 2012b. Corporate Social Responsibility and Global Labor Standards: Firms and Activists in the Making of Private Regulation. New York: Routledge.

Fransen, Luc. 2011. Why do private governance organizations not converge? A politicalinstitutional analysis of transnational labor standards regulation. Governance 24(2): 359-387.

Fransen, Luc, and Brian Burgoon. 2017. Introduction to the Special Issue: Public and Private Labor Standards Policy in the Global Economy. Global Policy 8(S3): 5-14. 
Fransen, Luc, Jelmer Schalk, and Graeme Auld. 2016. Work ties beget community? Assessing interactions among transnational private governance organizations in sustainable agriculture. Global Networks 16(1): 45-67.

Gardener, Daisy. 2012. Workers' rights and corporate accountability: The move towards Practical, Worker-driven change for sportswear workers in Indonesia. Gender \& Development 20(1): 49-65.

Helfen, Markus, and Michael Fichter. 2013. Building transnational union networks across global production networks: Conceptualising a new arena of labour-management relations. British Journal of Industrial Relations 51(3): 553-576.

Helfen, Markus O., Schüßler, Elke and Stevis, Dimitris. 2016. Translating European labor relations practices to the United States through global framework agreements? German and Swedish multinationals compared. ILR Review 69(3): 631-655.

Helfen, Markus, Elke Schüßler, and Jörg Sydow. 2018. How can employment relations in global value networks be managed towards social responsibility? Human Relations 71(12): 1640-1665.

House of Commons Environmental Audit Committee. 2019. Fixing Fashion: Clothing consumption and sustainability, London: House of Commons.

IndustriALL. 2019. Cambodian unions call on firms to ACT. Accessed at: http://www.industriall-union.org/cambodian-unions-call-on-brands-to-act (May 2019). 
Locke, Richard. 2013. The Promise and Limits of Private Power: Promoting Labor Standards in a Global Economy. Cambridge: Cambridge University Press.

Locke, Richard, Matthew Amengual, and Akshay Mangla 2009. Virtue out of necessity? Compliance, commitment, and the improvement of labor conditions in global supply chains. Politics \& Society 37(3), 319-351

Marginson, Paul. 2016. Governing work and employment relations in an internationalized economy: the institutional challenge. ILR Review 69(5), 1033-1055.

Merk, Jeroen. 2011. Production beyond the horizon of consumption: Spatial fixes and antisweatshop struggles in the global athletic footwear industry. Global Society 25(1): 7395.

Miller, Doug. 2011. Global social relations and corporate social responsibility in outsourced apparel supply chains: The Inditex Global Framework Agreement. In Konstaninos Papadakis (Ed.), Shaping Global Industrial Relations: The Impact of International Framework Agreements, pp. 179-198. Houndmills, Basingstoke: Palgrave Macmillan.

Miller, Doug, and Klaus Hohenegger. 2016. Redistributing value added towards labour in apparel supply chains: Tackling low wages through purchasing practices, Conditions of work and employment series No. 83. Geneva: ILO.

Offe, Claus, and Helmut Wiesenthal. 1980. Two logics of collective action: theoretical notes on social class and organizational form. Political Power and Social Theory 1(1): 67115.

Olson, Mancur. 1965. The Theory of Collective Action: Public Goods and the Theory of Groups. Cambridge: Harvard University Press. 
Oka, Chikako. 2018. Brands as labour rights advocates? Potential and limits of brand advocacy in global supply chains. Business Ethics: A European Review 27(2), 95-107.

O’Rourke, Dara. 2006. Multi-stakeholder regulation: privatizing or socializing global labor standards? World Development 34(5): 899-918.

Ostrom, Elinor. 2000. Collective action and the evolution of social norms. Journal of Economic Perspectives 14(3): 137-158.

Papadakis, Konstantinos. 2011. Adopting International Framework Agreements in the Russian Federation, South Africa and Japan: Management Motivations. In Konstantinos Padadakis (Ed.), Shaping Global Industrial Relations: The Impact of International Framework Agreements, pp. 61-81. Houndmills, Basingstoke: Palgrave Macmillan.

Prakash, Aseem, and Matthew Potoski. 2007. Collective action through voluntary environmental programs: A club theory perspective. Policy Studies Journal 35(4): 773-792.

Reinecke, Juliane and Jimmy Donaghey. 2015. After Rana Plaza: Building coalitional power for labour rights between unions and (consumption-based) social movement organisations. Organization 22(5): 720-740.

Reynaud, Emmanuel. 2017. The International Labour Organization and the Living Wage: A Historical Perspective, Conditions of Work and Employment Series No. 90. Geneva: ILO.

Schmitter, Philippe C., and Wolfgang Streeck. 1999. The Organization of Business Interests: Studying the Associative Action of Business in Advanced Industrial Societies, No. 99/1. Cologne: Max Planck Institute for the Study of Societies. 
Schuessler, Elke, Frenkel, Stephen. J., and Wright, Chris F. (2019). Governance of labor standards in Australian and German garment supply chains: The impact of Rana Plaza. ILR Review 72(3): 552-579.

Shift. 2018. ACT Initiative. Accessed at https://www.shiftproject.org/sdgs/living-wages/actinitiative/ (September 2018).

Siegmann, Karin Astrid, Jeroen Merk, and Peter Knorringa. 2016. Positive class compromise in globalized production? The Freedom of Association Protocol in the Indonesian sportswear industry. International Labour Review 156(3-4): 345-365.

Sowray, Bibby. 2012. H\&M accused of underpaying Cambodian workers. The Telegraph October 29, 2012. Accessed at http://fashion.telegraph.co.uk/newsfeatures/TMG9640180/HandM-accused-of-underpaying-Cambodian-workers.html (September 2018).

Streeck, Wolfgang. 1987. The uncertainties of management in the management of uncertainty: Employers, labor relations and industrial adjustment in the 1980s. Work, Employment and Society 1(3): 281-308.

Traxler, Franz. 1999. Employers and employer organisations: the case of governability. Industrial Relations Journal 30(4): 345-354.

Traxler, Franz. 2004. Employer associations, institutions and economic change: a crossnational comparison. The German Journal of Industrial Relations 42-60.

Turnaroundhm.org. 2018. Lost and found: H\&M’s living wage roadmap. Accessed at https://turnaroundhm.org/static/background-hm-roadmap0f39b2ebc3330eead84a71f1b5b8a8d4.pdf (September 2018). 
Vaughan-Whitehead, Daniel. 2010. Fair wages: Strengthening Corporate Social Responsibility. Cheltenham: Edward Elgar Publishing Limited.

Zajak, Sabrina. 2017. Transnational Activism, Global Labor Governance, and China. New York: Palgrave Macmillan. 


\section{Figures and Tables}

Figure 1: Situating TIRAs in private labor governance of supply chains

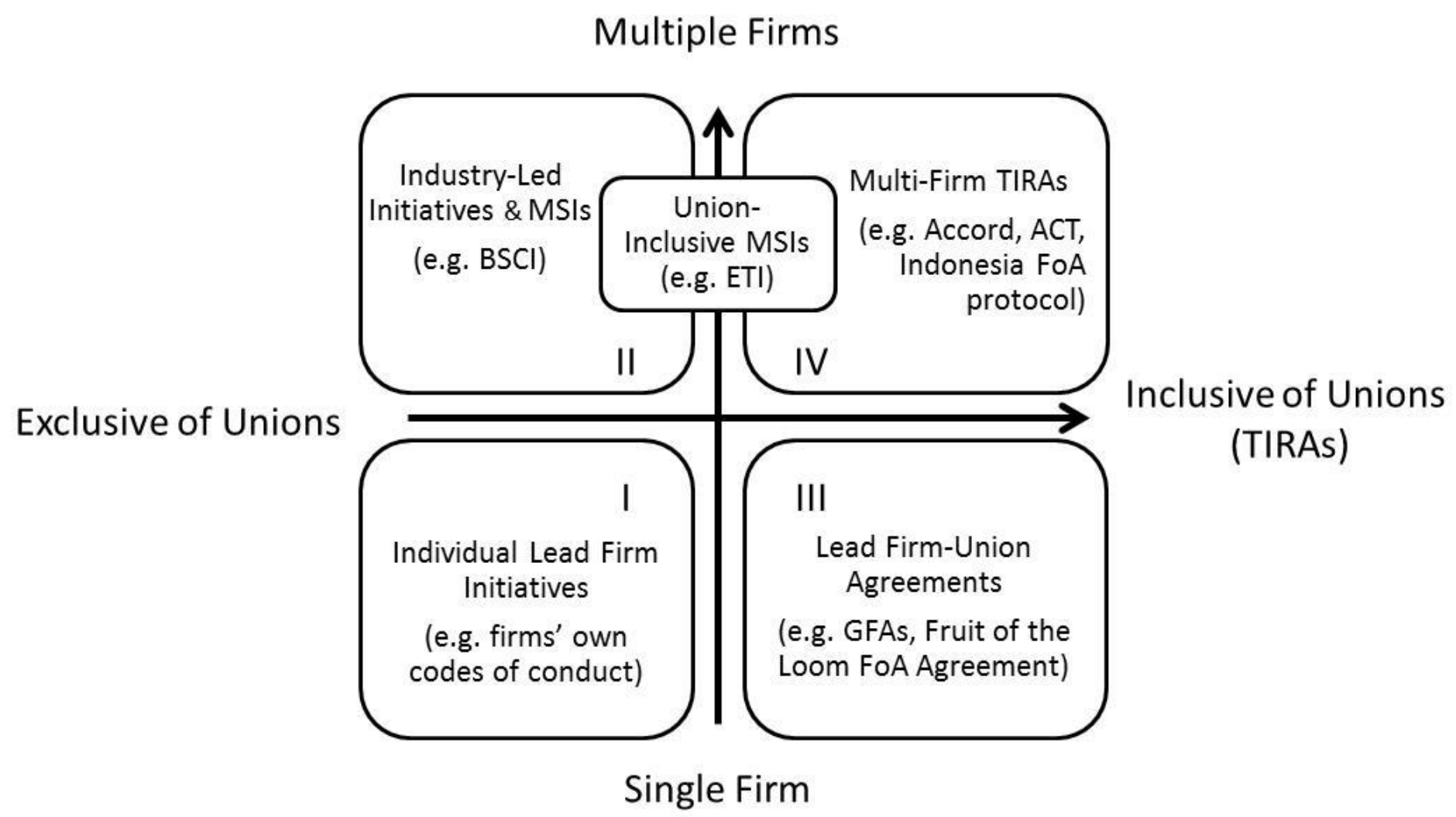

Acronyms: ACT (Action, Collaboration, Transformation), BSCI (Business Social Compliance Initiative), ETI (Ethical Trade Initiative), FoA (freedom of association), GFAs (global framework agreements), MSIs (multi-stakeholder initiatives), TIRAs (transnational industrial relations agreements) 
Table 1: ACT Founding Brands and Retailers

\begin{tabular}{|l|l|l|l|l|l|l|l|}
\hline Founder Firms & $\begin{array}{l}\text { Country of } \\
\text { Origin }\end{array}$ & Type & Ownership & Firm Size & Accord & GFA $^{\mathbf{2}}$ & ETI $^{\mathbf{3}}$ \\
\hline Arcadia Group & UK & Clothing Specialist & private & giant & Yes & No & No \\
\hline ASOS & UK & Online & publicly traded & very large & No & $\begin{array}{l}\text { Yes } \\
(2017)\end{array}$ & Yes \\
\hline C\&A & Germany & Department Store & private & very large & Yes & No & Yes \\
\hline Debenhams & UK & Department Store & publicly traded & very large & Yes & No & Yes \\
\hline Esprit & Germany & Clothing Specialist & private & large & Yes & $\begin{array}{l}\text { Yes } \\
(2018)\end{array}$ & No \\
\hline H\&M & Sweden & Clothing Specialist & publicly traded & giant & Yes & $\begin{array}{l}\text { Yes } \\
(2015)\end{array}$ & Yes \\
\hline Inditex & Spain & Clothing Specialist & publicly traded & giant & Yes & $\begin{array}{l}\text { Yes } \\
(2007)\end{array}$ & Yes \\
\hline N Brown & UK & Online & publicly traded & very large & Yes & No & Yes \\
\hline New Look & UK & Clothing Specialist & private & very large & Yes & No & Yes \\
\hline Next & UK & Department Store & publicly traded & giant & Yes & No & Yes \\
\hline $\begin{array}{l}\text { Pentland Group } \\
\text { UK }\end{array}$ & $\begin{array}{l}\text { Outdoor / Sports } \\
\text { Brands }\end{array}$ & private & giant & No & No & Yes \\
\hline Primark & UK & Clothing Specialist & private & giant & Yes & No & Yes \\
\hline Tchibo & Germany & Supermarket & private & giant & Yes & $\begin{array}{l}\text { Yes } \\
(2016)\end{array}$ & Yes \\
\hline Tesco & UK & Supermarket & publicly traded & giant & Yes & No & Yes \\
\hline $\begin{array}{l}\text { Topshop / } \\
\text { Topman }\end{array}$ & UK & Clothing Specialist & private & very large & $\begin{array}{l}\text { see } \\
\text { Arcadia+ }\end{array}$ & $\begin{array}{l}\text { see } \\
\text { Arcadia+ }\end{array}$ \\
\hline
\end{tabular}

${ }^{1}$ Accord for Fire and Building Safety in Bangladesh

${ }^{2}$ Global Framework Agreement

${ }^{3}$ Ethical Trading Initiative 
* Firm Size is classified based on Lane (2008). General (incl. non-textile), worldwide annual turnover of firms classified as follows: very small, less than $€ 50$ million; small, $€ 50-249$ million; medium, €250-499 million; large, $€ 500-999$ million; very large, $€ 1,000-2,999$ million; giant, more than $€ 3,000$ million.

+ Topshop/Topman is owned by Arcadia Group Limited. It joined ACT independently of Arcadia for reasons which are difficult to explain without compromising anonymity. 